\title{
Some Notes on Thematics, Topic, and Typology
}

\section{Hakulinen, Auli}

John Benjamins

1989

Hakulinen , A 1989 , Some Notes on Thematics, Topic, and Typology . in M-E Conte , J S Petöfi \& E Sözer (eds), Text and Dsicourse Connectedness : Proceedings of the Conference on Connexity and Coherence 16-21.7. 1984 . 1. edn , vol. 16, 5 , Studies in Language Companion Series, vol. 16 , John Benjamins , Amsterdam , pp. 53-63 .

http://hdl.handle.net/10138/236517

cc_by

publishedVersion

Downloaded from Helda, University of Helsinki institutional repository.

This is an electronic reprint of the original article.

This reprint may differ from the original in pagination and typographic detail.

Please cite the original version. 


\title{
Some Notes on Thematics, Topic, and Typology
}

\author{
Auli Hakulinen
}

\section{Summary}

This paper is a critical discussion of the notion of sentence theme from the point of view of a pragmatically flexible, non-Indo-European language, i.e. Finnish.

One might wish to make a thematic analysis of the sentences in a genuine text, for the purposes of understanding the thematic progress characterising the text. When doing this, one soon finds that a semanticopragmatic notion of sentence theme defined as 'what the sentence is about' is without value. On the other hand, the position held by, e.g., Halliday that theme is the leftmost constituent of a sentence, is equally intolerable in a language of this type. In a language which is not strictly SVO, the sentence initial position in a declarative sentence is used for a number of purposes, not solely for bringing up the theme of the sentence. For this reason, thematics should orient itself more to rhetorics - a half-way house between syntactic typology and text semantics. Otherwise we shall go on pretending that sentence theme is a language indepedent notion like discourse topic, which of course it isn't.

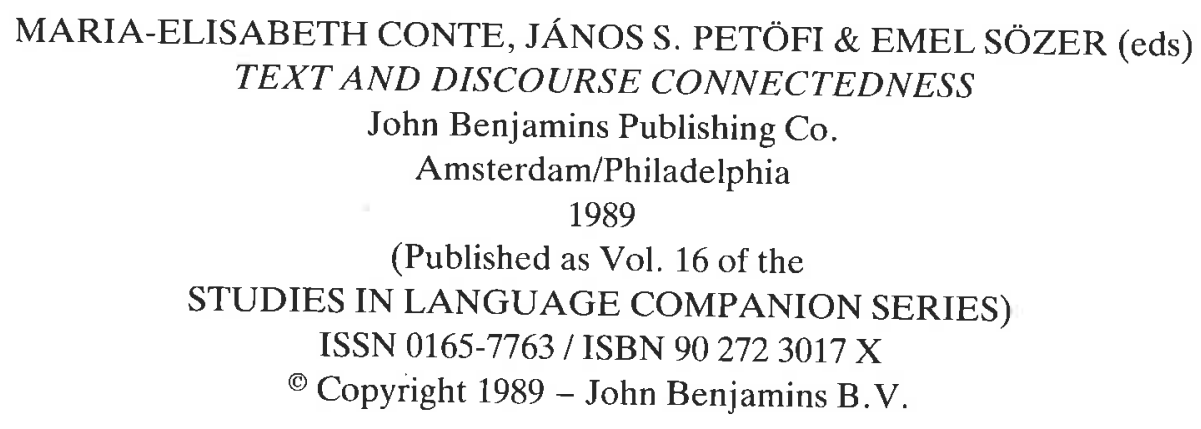

(Published as Vol. 16 of the

STUDIES IN LANGUAGE COMPANION SERIES) ISSN 0165-7763 / ISBN $902723017 \mathrm{X}$

() Copyright 1989 - John Benjamins B.V.

No part of this book may be reproduced in any form, by print, photoprint, microfilm or any other means, without written permission from the publisher.

In his recent textbook on pragmatics, Stephen Levinson expresses a view, probably shared by many theoretically oriented discourse analysts, namely that the analysis of topic/comment or theme/rheme structure in sentences is, at present, in such bad shape that it is best left undiscussed in any level-headed presentation of the state of the art: "Terminological profusion and confusion, and underlying conceptual vagueness, plague the relevant literature to the point where little may be salvageable. For example, whereas we may be told how to identify a topic in a simplex declarative sen- 
tence, we are never told how to identify the topic of a sentence of arbitrary complexity (i.e. we are never offered a projection principle) (1983:X). He believes, like so many others do, that "the whole area may be reducible to a number of different factors: to matters of presupposition and implicature on the one hand, and to the discourse functions of utterance-initial (and other) positions on the other". Elsewhere in his book, Levinson has a lengthy passage on the topic of discourse - a concept that he apparently feels comfortable with but which he himself does not even attempt to define.

Despite the enormous difficulties presented by any attempt at clarification in this messy field, I will try to approach the issue from a typological point of view. That is, I am going to discuss the problematic status of sentence theme from the point of view of syntactic typology. Also, I am going to point out the implications of this criticism for the problems of thematic progress, which is one way of explicating discourse topic. Before doing that, let me briefly outline the overall problem as I see it.

The notion of discourse topic is intuitively clear, but attempts at pinning it down in an objective way have not been very successful. In certain instances, when the text is simple enough, its topic may be characterised with a single phrase, e.g. "The squirrel", or "A pilgrimage". With complex texts, however, there might be a multitude of ways of telling what the text is about, and even one listener or reader might characterise the text in several different ways. The problems with objectivity in the explicating of the topic of a text are due to the fact that discourse topic is first and foremost a pragmatic notion. In other words, it is the speakers who have topics, not in fact texts. Therefore, what one is explicating is not only what is literally there but also what has been implied in the text, both conventionally and conversationally. From the point of view of the addressee, and also of the analyst, the meaning of a text is created not only through the sentences that it is composed of, but also of the inferences that the reader will go through in the process of interpreting the text.

This is the reason why e.g. Brown and Yule (1983: 110) are prepared to state quite categorically that a propositional analysis of a text, aiming at the explication of its discourse topic, is at best only one of its possible interpretations. Moreover, it is usually one which ignores the textual, or communicative aspects of the discourse in question.

In my opinion, Brown and Yule are on the right track when they specify the discourse topic as consisting of "the important elements of the discourse content" (1983: 107). Even this is vague as it stands, but it definitely means an opening towards a pragmatic treatment of the intuitive notion of discourse topic.

Whereas discourse topic is language independent, sentence theme is not, although it is quite often talked about as if it were a universal or language-independent notion. If sentence theme is given a purely semanticopragmatic definition, e.g. if it is defined as "what the sentence is about", sentence theme is a priori treated as part of and parallel with discourse topic. This will, however, easily lead us to arbitrariness, as is illustrated by van Dijk's treatment (1977). He states explicitly that anything in a sentence may form its topic, and that the sentence topic "cannot possibly coincide with or be identical to particular syntactic categories" (1977: 116). In other words, this way of looking at sentence theme comes very close to what Brown and Yule have called "topic entities", referents in the universe of discourse which may appear in any order in the sentence structures of a discourse. For the ordinary working discourse analyst, this purely semantic approach to sentence theme is unsatisfactory. This is because I think it is our primary consideration to interpret the effect of using one sentential form rather than another in the context of discourse. Thus, the notion of theme or sentence topic must have a rhetorical dimension as well: thematics must have something to do with the staging, or linear presentation of topic entities rather than purely with aspects of the content of the discourse. There are usually more topic entities in the universe of discourse than there can be sentential themes. What we must find out is to what extent the thematic choices made by a speaker or writer will influence the reader's intuitive notion of "gist", or important points in the discourse content. If it were to be shown that in certain kinds of texts, the rhemes contribute equally as much to the evolving of the discourse topic as the themes do, we could say that it is a harmful coincidence that both the initial position of the sentence, and the gist of a text, have come to be called by the same names. If, on the other hand, we manage to come up with a reliable notion of sentence theme, we might be able in the long run to show just how, in different types of languages, syntactic presentation is made to serve the organisation of information flow, helping the receiver to interpret the message, and to memorise the main points in it. 


\section{Syntactic typology and sentence theme}

One of the outcomes of the recent research on grammatical universals or grammatical typology has been the gradual crumbling of the SVOpower. Since $\mathrm{Li}$ (1976), it has become more and more evident that subject is a category which is most usable for the analysis of languages with a strict SVO order. For others, whether VSO or "topic oriented" or what have you, it is of less use, possibly downright harmful. In many recent discussions, it has been pointed out that subject is somehow at the cross-roads between Agent and topic (e.g. Comrie 1981). The contents of the notion of topic is usually left unexplained; topic is referred to as a "pragmatic role".

Despite the enormous amount of grammatical clarification that typological studies have produced, the notion of theme or sentence topic seems - at least to me - still to suffer from an Anglo-Saxon bias. In English, the left-most constituent and the subject of the sentence often collapse, and in narrative discourse these even coincide with the "main character" of the story. Givón (1983) has been working at the border-line of discourse and syntax, and has also tried to capture the difference between an SVO and a non-SVO, or what he calls a pragmatically flexible language. The latter is, according to him (1983: 33), "undercoded in the functional domain of topic continuity - as far as the use of word order is concerned, as compared to (...) a rigid SVO language". In other words, in languages which are not subject oriented, "topic continuity" is not served as clearly by word order (or by the sentence initial position?) as it is in English, where something thematic must turn up in the initial position of a clause and a sentence. As the typological predominance of SVO languages has led linguists to look for subjects in any kinds of language, the obligatoriness of sentence theme in these languages has led us to worry inordinately about languages where the message and the code part ways to a greater degree than in English. What I mean is, simply, that in "pragmatically undercoded" languages, there is no obligation for theme to be realised as a constituent at all (or at least not always as a sentence initial constituent).

Finnish is, as far as I can understand, a pragmatically flexible word order language, which, under a heavy and prolonged Indo-European influence, has acquired many characteristics of an SVO language as well. In "system sentences" (Lyons 1977: 387), Finnish has three alternative word order patterns, SVO (1), (A)VS (A)VC (2), and AVX (3):
(1) a. Mies maalasi ahkerasti. man painted busily 'The man was painting busily.'

b. Eläimet ovat kuluttajia. animals are consumers

'Animals are consumers.'

c. Kaikki luulivat häntä Kekkoseksi. all thought him kekkonen:TransL. 'Everybody thought him to be Kekkonen.'

(2) a. Tuli kevät. came spring 'It became spring.'

b. Kuului ääniä. heard:PAss voices

'Voices were heard.'

c. Verho-on paloi reikä. curtain:ILLAT. burned hole 'A hole was burned in the curtain.'

d. Einsteini-sta tuli nero. Einstein:ELAT. came genius 'Einstein became a genius.'

(3) a. Poja-lla on rahaa. boy:ADEss. is money 'The boy has money.'

b. Onnettom-ia avioliitto-ja on enemmistö. unhappy:PART marriages:PART. is majority

'The majority of marriages are unhappy.'

Thus, in a grammatical description of Finnish, the subject is not an obligatory (if even a necessary) constituent. There is no formal subject in the language, and the passive construction is a so-called impersonal one, with the chief motivation of getting rid of the Agent NP, never promoting a non-agent to the subject position. When there is a constituent which resembles subject in the sentence, it does not have to occur in the initial position. Although in simple narrative texts, where agentive actants abound, the thematic subject may to a large extent resemble that of the corresponding English text; in other types of discourse the subject is more seldom thematic than it is in English. 
From these typological facts there follow others which cause difficulties for any consistent approach to the identification of theme in Finnish text sentences.

Firstly, a declarative sentence may, for a number of reasons, be verb initial, or it may consist of a verb alone. If we go by a positional criterion when making a thematic analysis of sentences, theme has no longer anything to do with the semantics of a sentence: it would not foreground one of the topic entities of the sentence, as in an English declarative sentence, nor would it reveal the modal status of the sentence as, for Halliday, the initial verb of an interrogative or an imperative sentence would do. Let us look at some examples (cf. also examples $2 \mathrm{a}$ and $2 \mathrm{~b}$ above):

\section{(4) a. Sataa. Tuulee. \\ rains winds \\ 'It is raining. The wind is blowing.' \\ b. Pelottaa. \\ frightens \\ 'It is frightening; I feel frightened.'}

(5) a. Em-me voi hyväksyä tätä. not:V:we can accept this

'We cannot accept this.'

b. Ole-n yksin.

be:I alone

'I am alone.'

(6) a. Saunotti-in.

bathed:PAss

'People were having sauna.'

b. Menti-in uimaan.

went:Pass swimming

'People went swimming.'

c. Tarvita-an lisää teoreettista työtä.

need:pass more theoretical work

'More theoretical work is needed.'

There is no nominal theme in a meteorological sentence (4); the first and second person subject pronouns can be dropped, as the person is manifest in the verb (5). The "passive" construction never has an explicit subject constituent, but it conventionally implicates that there is a non-specific + human Agent in the works (6). In instances of this kind, one is tempted to view the theme not as a constituent, but as a pragmatic notion, something that the reader knows is being talked about in the sentence although it is not presented in the form of an initial constituent. Rhetorically speaking, there is no staging, or foregrounding, at least not in the way we envisage that staging should take place: the writer has either been forced by the language (as in (4)), or she has opted for a thematic zero (in (5), and in (6c)). If we still wish to hold on to the positional criterion, we may say that in these instances there is a zero-theme as a rhetorical choice. Let us look at a couple of other examples:

(7) a. Ei tässä ole mitään järkeä. not:V here be any reason 'There is no sense in this.'

b. Ei B:llä ole samaa suhdetta menneisyysteen not:V B:ADEss be same relationship past:ILLAT kuin C:llä. as C:Adess.

' $\mathrm{B}$ does not have the same kind of relationship to the past as $\mathrm{C}$.'

(8) a. On-han tässä kirjoituksessa paljon hyvääkin. is:CLIT. this writing:INEss. much good 'There is admittedly a lot of good stuff in this paper.'

b. On Mikko käynyt siellä ennenkin. is Mikko visited there before 'Mikko has indeed been there before.'

In two kinds of declarative sentence, the verb is often in sentence initial position. In example (7), we have the negative verb ei initially, and it is followed by a nominal constituent which could very well be taken as the theme of the sentence. The difference between a verbal and a nominal beginning is not great, the alternatives seem to vary freely. Thus, the decision that the negative verb, when sentence initial, would somehow represent a marked theme, thereby marking the whole sentence construction as deviating from the main line of the story, would be counter intuitive.

The sentences in (8) which begin with the affirmative verb, are used as responses - either they express admittance of a fact which has become evident from the context, or they express disagreement with something that has been said before. The position of the verb reveals the speech function of the sentence, which is something different than forming its theme. In a system like Halliday's, where verbs are acceptable as themes, a blending of 
two phenomena seems to take place: we cannot clearly keep thematics and sentence function apart from each other.

The third instance of verb-initialness is less interesting, but needs to be mentioned for the sake of completeness:

(9) a. (Vaikka kokeiluun tuleekin saada valtionapua), although experiment needs getting government assistance 'Although it is necessary to get government assistance for the experiment,'

on sen toteuttaminen mahdollista ilmankin.

is its realisation possible without

'realizing it will be possible even without the help.'

b. Silloin tällöin, parin tunnin väliajoin, katkaisi ohikulkeva then now couple hour's interval broke passing

juna hiljaisuuden.

train the silence

'Now and then, at two hour intervals, a passing train broke the silence.'

In the Finnish grammatical literature, these instances are labeled as inversions. Presumably due to Swedish influence, the verb gets placed in second position when the sentence begins with an adverbial clause, or otherwise a long adverbial. In these instances, it would be pointless to talk about a thematic decision, and we can pick the theme from the position immediately after the finite verb.

The fronting of an adjectival predicate complement yields yet another kind of sentence beginning and other kinds of problems for the progression of theme:

(10) a. Raskasta on yrittää uudelleen.

heavy is try again

'It is difficult to keep trying.'

b. Pitkä oli matka kauppoihin, kapakoihin ja valaistuille long was way shops:Illat. bars:ILlat. lighted kaduille.

streets: ALLAT.

'It was a long distance from shops, bars and streets with lights on.'

c. Hulluja ovat nämä nuoret intomielet!

foolish are these young enthusiasts

'These young enthusiasts ara a bunch of fools!'
There can be several reasons for the complement to get fronted, or topicalised - none of these seems to have much to do with thematics. Here, one feels tempted to state that the sentence initial position is not simply reserved for the theme, or for revealing the sentence function, as in the previous sections, but for expressing the attitude of the speaker. The predicating adjectives, when fronted, seem to manifest the same function as sentence initial comment adverbs do. If this view can be accepted, sentences of type (10) could be analysed as being themeless.

On the other hand, the finite verb in Finnish may be preceded by two (occasionally by three) nominal constituents, each of which may be an obligatory argument of the verb:

(11) a. Turussa kaikki myytiin loppuun.

Turku:iness all sold:PAss end:ILLAT.

'In Turku, everything was sold out.'

b. $R$ oli keksinyt uuden ansaitsemiskeinon:

$\mathrm{R}$ was invented new earning means

maaseutunäyttelyt.

country exhibitions

' $R$. had invented a new way of making money: country exhibitions.'

c. Niitä hän harrasti monta vuotta. Mutta rahat hän joi those he practised many years but money he drank heti.

at once

'He did those for several years to come. But he drank all the money at once.'

(12) Vanha nainen piti kissasta ja särkyneestä sydämestä. old woman liked cat and broken heart

Mutta kirvoista hän ei pitänyt.

but bugs she not liked.

'The old woman liked the cat and the broken heart (plant), but she did not like the bugs.'

Here we see quite clearly that the pre-verbal position can be used, simultaneously, for the placing of a given theme (he, the artist $\mathrm{R}$ that the whole book is about), and in front of that, a temporary theme, which has a link to the immediately preceding sentence(s): niitä ('those') $\leftarrow$ maaseutunäyttelyt; rahat ('money') $\leftarrow$ ansaitsemiskeino. In Finnish, the position immediately preceding the finite verb seems to be preserved for a 
given constituent, whether we like to call this theme or not. In front of this we might get either a temporary theme, as in the instances of (11), or a contrastive, even wholly new constituent (12): a fact that goes against the principle of communicative dynamism once put forward by Firbas.

If the positional criterion is taken here to be the leading one, we could say, as Brown and Yule in fact do $(1983 ; 143)$, that the topic entity, $R$ is thematic only in sentence (b) of example (11). In (c) and (d) hän ('he') is given, but not thematic. Alternatively, if we stick to the thematic progress in a text, we could say that it is not the very beginning of the sentence which is reserved for the theme, but the position immediately preceding the finite verb. The initial, or "topical" position, on the other hand, is reserved for a number of purposes, most of which can be lumped under a general heading of having to do with sentence function: bringing up the opinion of the speaker; linking the sentence with the immediately preceding one; putting forth contrasting or controversial information.

Seen from another point of view, this state of affairs might be one where the communicative point of departure (the theme), and the cognitive point of departure (psychological subject) part ways, and we must resist our "natural tendency" (Lyons 1977: 508) to have these two always coincide. However we might solve the issue, the thematic development in a text easily becomes polyphonic.

It will have become obvious from my brief presentation that the wider the range of choices in the sentence initial position in a language, the less help an analyst has from an exclusively positional definition of a theme. If we follow the principle of picking out the initial elements and labeling them as themes, we get absurd results for the description of thematic progress in a text as a whole. If, on the other hand, we accept a purely semantic definition of the theme, we thereby drop the aim of trying to understand the interplay of discourse and syntax, or the textual rhetorics available for the language in question. What we need, then, is a procedure which enables us to avoid the arbitrariness of leaving syntax completely outside the analysis, and which defines the thematically relevant positions for each language at a time. We do not wish to end up with an analysis where the textual rhetorics is exclusively tied up with the typological characteristics of a language. In order to be able to speak about rhetorics at all, we must be able to claim that there is a leeway for choices which are due to the type of text in question, or due to the preferences made by the individual speaker/writer. We must be able to sort out the "permanent likelihoods" dictated by grammar before we can understand the room left for individual choices in a single text.

\section{References}

Allén, Sture (ed.) 1982. Text Processing. Proceedings of Nobel Symposium 51. (= Data Linguistica 16) Gothenburg.

Brown, Gillian and Yule, George. 1983. Discourse Analysis. Cambridge etc.: Cambridge Textbooks in Linguistics.

Chafe, Wallace L. 1976. "Givenness, contrastiveness, definiteness, subjects and topics". Li (ed.) 1976.

Comrie, Bernard. 1981. Language Universals and Linguistic Typology. Oxford: Basil Blackwell.

Givón, T. 1983. Topic continuity in discourse: an introduction. In: Givón (ed.) 1983.

---. (ed.) 1983. Topic Continuity in Discourse: a quantitative cross-language study. Amsterdam: John Benjamins.

Grimes, Joseph E. 1982. Topics within topics. In: Tannen (ed.) 1982.

Hakulinen, Auli, Karlsson, Fred and Vilkuna, Maria. 1980. Suomen tekstilauseiden piirteitä; kvantitatiivinen tutkimus. (= Publications of the Department of General Linguistics, University of Helsinki, Nr. 6). Helsinki (= Features of Finnish Text Sentences, a quantitative study)

Kohonen, Viljo and Enkvist, Nils Erik (eds.) 1978. Text Linguistics, Cognitive Learning and Language Teaching. (= AFinLA Publications N:o 22.) Turku.

Lautamatti, Liisa. 1978. Observations on the development of the topic in simplified discourse. In: Kohonen and Enkvist 1978.

Levinson, Stephen. 1983. Pragmatics. Cambridge, etc.: Cambridge Textbooks in Linguistics.

Li, Charles N. (ed.) 1976. Subject and Topic. New York, etc: Academic Press.

Longacre, Robert E. 1982. Discourse typology in relation to language typology. In: Allén (ed.) 1982.

Lyons, John. 1977. Semantics 1 \& 2. Cambridge etc.: Cambridge University Press.

Tannen, Deborah (ed.) 1982. Analyzing Discourse: Text and Talk. (= Georgetown University Round Table on Languages and Linguistics 1981). Washington D.C.

van Dijk, Teun A. 1977. Text and Context. Explorations in the Semantics and Pragmatics of Discourse. (= Longman Linguistics Library 21). London: Longman.

---- 1981. Studies in the Pragmatics of Discourse. The Hague; Mouton. 